\title{
Quantification of the Impact of Integrated Soil and Water Conservation Measures on Groundwater Availability in Mendae Catchment, Abraha We-Atsebaha, eastern Tigray, Ethiopia
}

\author{
Tireza Negusse, Eyasu Yazew and Nata Tadesse* \\ Department of Earth Science, College of Natural and Computational Sciences, P.O. Box 3066, \\ Mekelle University, Mekelle, Ethiopia (*tafesse24603@yahoo.com)
}

\begin{abstract}
The paper tries to evaluate the impact of integrated soil and water conservation measures on water availability in Mendae catchment $\left(10.37 \mathrm{~km}^{2}\right)$, which is located in the northeastern Tigray. Historical background of the catchment with respect to its land use was obtained from the local Bureau of Agriculture and Rural Development office. The hydrology of the area was characterized based on its land use, soil, slope, rainfall, temperature, evapotranspiration, and runoff. Thornthwaite method and Thornthwaite soil-water balance model were used to determine potential and actual evapotranspiration, respectively. The mean annual runoff from the catchment was computed using runoff coefficient method. Before the intervention, the area was severely degraded and known with scarcity of water. Integrated soil and water conservation (physical and biological measures) was introduced to the area since 1993. The catchment is characterized by two rainy season and three dry seasons during the year. The rainy seasons in total have four months whereas the dry seasons comprises of eight months. The mean annual rainfall of the catchment is $565.8 \mathrm{~mm}$, out of which rainy season accounts for $86.13 \%$ and the dry season for $13.87 \%$. The rain that occurs with a very high concentration accounts $73.20 \%$ of the mean annual rainfall of the catchment and this occur only in two months (July and August).The mean annual potential and actual evapotranspiration was found to be $832.67 \mathrm{~mm}$ and $405.61 \mathrm{~mm}$, respectively. The volume of runoff before and after the intervention was found to be $26.88 \%$ and $17.19 \%$ of the mean annual rainfall of the catchment, respectively. The groundwater recharge before and after the intervention was found to be $1.43 \%$ and $19.04 \%$ of the mean annual rainfall of the catchment, respectively. The availability of groundwater has increased more than 10 times since 1993. Though the groundwater is being used for both complimentary and supplementary irrigation during the dry and rainy season, respectively, construction of additional physical conservation structures is suggested to further improve the groundwater availability in the area.
\end{abstract}

Keywords: Groundwater, Mendae catchment, Surface runoff, Water balance, Tigray, Ethiopia.

\section{INTRODUCTION}

Deforestation, increased runoff and soil erosion are serious problems in Ethiopia. Rapid population growth, improper land resource management and utilization are the principal causes of increased runoff and soil erosion in Ethiopia. It has resulted in declining agricultural 
productivity, water scarcity and continuing food insecurity (Badege, 2001).On the other hand, the demand of adequate water for domestic purpose, irrigation activities and in general water for production is increasing. Tigray is one of the regions of Ethiopia that suffer from sever land degradation. Among others, overgrazing, deforestation and soil erosion account for the most observable land degradation phenomena. Deforestation and improper land management contributes to high soil erosion, flood hazard, sedimentation and less available water in the region. In Tigray, water is a scarce resource and it is one of the main constraints that affect crop production.

To overcome these problems, since the early 1990's integrated soil and water conservation activities have become one of the major preoccupations of the people and the authorities of Tigray region, where the study area, Mendae catchment, is located. This has involved mass mobilization of labor during the dry season, as well as food-for-work and cash-for-work programs. In addition, there have been efforts to promote natural regeneration of degraded lands by establishing area enclosure and afforestation (Fitsum et al., 1999).Very degraded areas are even closed to enhance the natural regeneration of native plant species and reduce velocity of rain drops and run off generation thereby increasing the infiltration.

In the study area, the extension system was also given a greater emphasis for integrated soil and water conservation measures as part of general land management and productivity enhancing practices and as a practical tool to conserve water. However, the impact of integrated watershed management on water availability in the study area with respect to before and after the intervention is not documented. Thus, the present paper tries evaluating the impact of integrated soil and water conservation measures on water availability in the area. .

\subsection{Description of the Study Area}

\subsubsection{Location}

The study area, Mendae catchment, is located in Aberha Atsebha Woreda, northeastern part of Tigray. Geographically, it is located between 1526000 to $1532000 \mathrm{mN}$ and 550000 to 556000 $\mathrm{mE}$ and has an area of about $10.37 \mathrm{~km}^{2}$ (Fig 1).

The Mendae catchment consists of small depressed area that extends from southeast to northwest bounded by steep highlands in west, southwest and south, and Suluh River in the east, northeast and south east. The maximum elevation is $2399 \mathrm{~m}$ above sea level in the southwestern part 
whereas the minimum is $1940 \mathrm{~m}$ above sea level in the flatland. Steep slopes cover the northwestern, western and southwestern part of the study area.

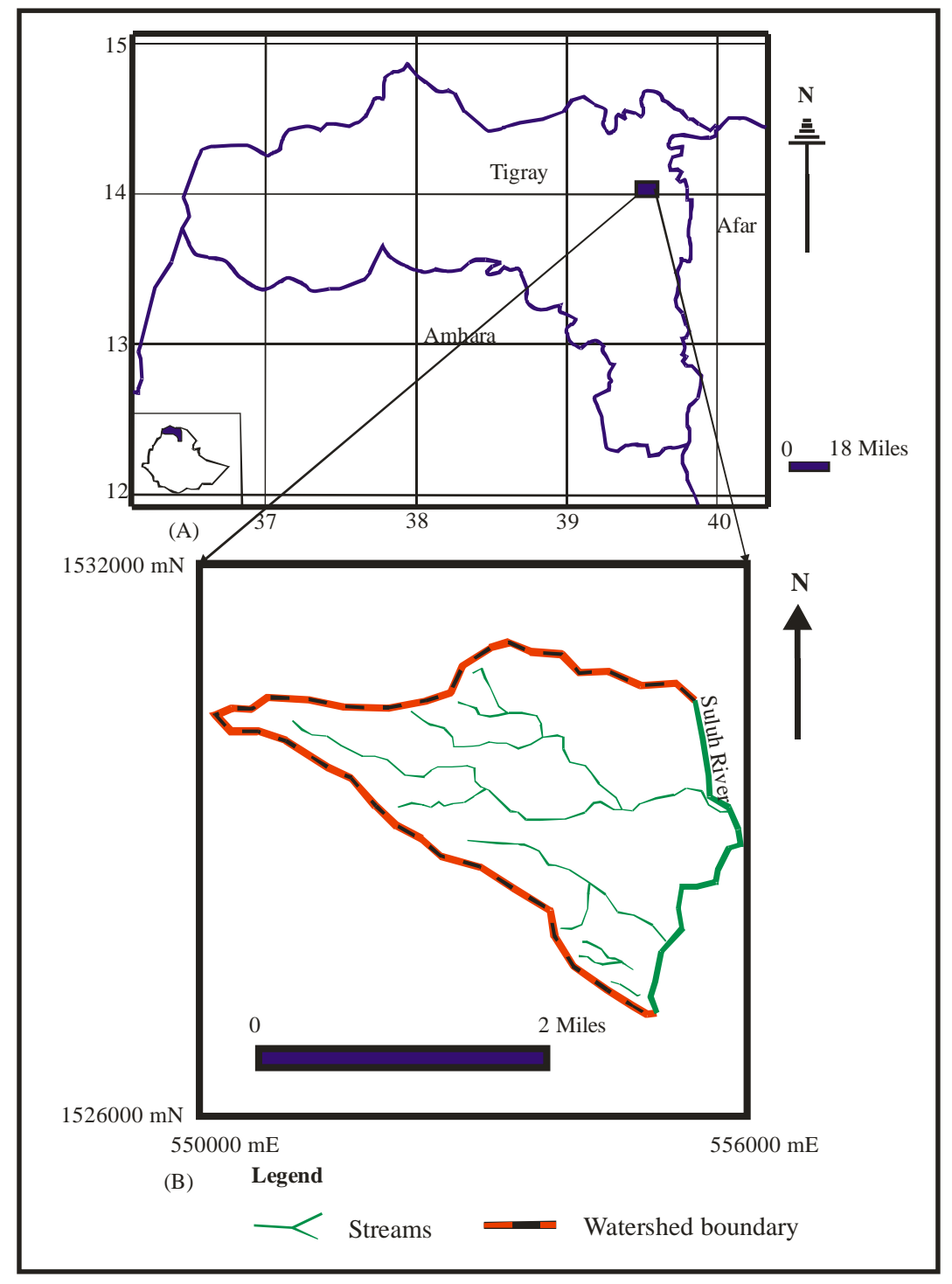

Figure1. Location map of the study area.

The study area is the western part of the Suluh River, which is a tributary of the Tekeze River. It is the largest river in the catchment that flows from north to south. Besides to this perennial river, the seasonal streams that drain the area are originated from the surrounding highlands and flow to east and southeast to the Suluh River. The streams are dense at the area of higher slope and get rare where the slopes are flat. In the catchment, the total stream length is $21.9 \mathrm{~km}$ and drainage 
density is $2.1 \mathrm{~km} / \mathrm{km}^{2}$. Generally, the catchment has dendritic drainage pattern (Fig 1) and the main source of water for the streams is rainfall.

The study area is covered by different soil textural groups. Sandy, sandy loam, clay and loamy sand are the main soil types and among these, sand is the dominant textural class. It is found covering the area starting from the upper north part to the lower flat area. In general, the nature, thickness and distribution of the soils varies depending on the slope of the study area: thin soil deposits that are relatively coarse are found on steep slope being deposited along the fractures the rocks whereas thick and fine grained soil deposits are found in the flatland.

The land use pattern in the area can be classified in to cultivated land, grazing land, area closure (bush land), home stead and bare land. The cultivated land commonly used for wheat, maize, and others cereal crop production. Currently the farmers use their lands both for cereal crops production and vegetables like cabbage, tomato, chills, onion and fruits by using groundwater as a source for irrigation.

\section{METHODOLOGY}

\subsection{Data collection}

Topographic map with a scale 1:50,000 (1339B1and 1339A2) was used to prepare the base map of the study area. The primary and secondary data were collected from the field and agricultural offices, respectively. CropWat, ArcView GIS 3.2 and CorelDRAW 12 software's were used for mapping purposes and for data analysis.

\subsubsection{Soil and Land Use}

The soil samples were taken based on the land use of the catchment. Moreover, field observation and feeling method was used to determine the number of sample pits that should be taken. Accordingly, seven soil sample pits were taken for the collection of desired soil data. The depth of the sample pits that should be considered was determined based on the average root depth of different vegetations in the study area. Disturbed and undisturbed soil samples were taken from $130 \mathrm{~cm}$ deep pit opened at 0-40 cm, 40-80 cm and 80-130 cm interval. The pits were opened at the aforementioned interval based on the type of soil profile. In order to determine the available water holding capacity of the soil, average root depth of different vegetations were measured in the field using tape meter. In addition, the current land use and soil texture data were collected in 
the field and the land use data of the catchment before intervention was collected from the local Bureau of Agriculture and Rural Development (BoARD) Office of the area (Woreda Office).

\subsubsection{Characterization of Soil and Water Conservation Measures}

Transect walk was made to identify the major physical soil and water conservation practices implemented in the upper catchment. Characterization of physical conservation was made based on dimension measurement. Dimensions were measured using tape meter and graduated stick.

\subsubsection{Meteorological data}

The meteorological data required to determine the basic hydrological parameters were obtained from Wukro and Senkata meteorological stations. The relative humidity of eight years (20022009), wind speed of six years (2004-2009) and sunshine hour of nine years (2001-2009) data were collected from Senkata meteorological station, which is a $1^{\text {st }}$ class station located about 40 Km far from the study area. Rainfall of eighteen years (1992-2009), mean maximum and minimum temperature of eighteen years (1992-2009) data were obtained from Wukro meteorological station, which is a $3^{\text {rd }}$ class station located about $20 \mathrm{Km}$ from the study area.

\subsection{Data Analysis}

\subsubsection{Soil Analysis}

In order to have representative soil sample, composite samples were prepared and taken to laboratory for grain size analysis using hydrometric method. The USDA soil textural classification system was used for the determination of textural class of the soil samples.

The moisture content of the soil at permanent wilting point (PWP) and field capacity (FC) was determined from collected soil samples. In this case the soil samples were saturated, a state where all pore spaces are filled with water and pressure of 0.33 bars and 15 bars were applied for FC and PWP, respectively. Then, the samples were taken to oven to dry and estimate the moisture content held in the soil at FC and PWP.

Accordingly, the laboratory analysis was made using;

Gravimetric Moisture content (MC) at FC = (weight of water/weight of dry soil)*100

Volumetric Moisture content at FC $=$ Gravimetric Moisture content at $\mathrm{FC} *$ Bulk density

Gravimetric Moisture content at PWP $=$ (weight of water/weight of dry soil $)^{* 100}$

Volumetric Moisture content at PWP $=$ Gravimetric Moisture content at PWP * Bulk density

According to Stephen (1999), available moisture content is given by:

Available moisture content $(\mathrm{AWC})=\mathrm{MC}$ at $\mathrm{FC}-\mathrm{Mc}$ at $\mathrm{PWP}$ 
Then, the available moisture content for each profile and the total available moisture content through the entire profile were determined for each dominant soil type. In this case different soil layers with different AMC were summed up layer-by-layer as follows (Stephen, 1999):

$\mathrm{TAM}=\left(\mathrm{AMC}_{1}\right)\left(\mathrm{L}_{1}\right)+\left(\mathrm{AMC}_{2}\right)\left(\mathrm{L}_{2}\right)+\ldots\left(\mathrm{AMC}_{\mathrm{N}}\right)\left(\mathrm{L}_{\mathrm{N}}\right)$.

Where, $\mathrm{L}=$ thickness of soil layer; 1,2 and $\mathrm{N}_{\mathrm{N}}$ subscripts represent each successive soil layer. Taking the average root depth of different crops and vegetations that dominantly grown in the catchment, the soil water holding capacity up to the active root zone was estimated so as to determine the actual evapotranspiration.

The actual soil moisture storage (SM) was computed using the basic equation (Thornthwaite and Mather, 1957).

$\mathrm{SM}=\mathrm{SWHC} * \mathrm{e}^{\mathrm{APWL} / \mathrm{SWHC}}$

Where, SM in mm; APWL -accumulated potential water loss (mm); SWHC is soil water holding capacity $(\mathrm{mm})$.

\subsection{Water balance}

All water balance equations are based on the premise that the difference between water inflow and out flow over a given time period for the hydrologic system must be equal to the change in water storage in that system (Radwan, 2009). This would mean:

Inflow - Outflow \pm Change in storage $=0$

The main purpose of this computation is to make a quantitative evaluation of the amount of water that percolate into the ground to recharge the groundwater circulation occurring in the investigated area before and after the intervention.

Various assumptions have been made to derive the water balance equation for the studied area and these are summarized below:

1. Since the computations are made on annual basis, net change of soil moisture and groundwater storage is assumed to be zero.

2. Subsurface water exchange with neighboring basins is assumed to be zero.

3. Assuming no artificial diversion from other basins.

For the case of the study area, the above general equation is reduced into the following form.

$\mathrm{P}-(\mathrm{AET}+\mathrm{Q})=\mathrm{GW}_{\mathrm{R}}$

Where, $\mathrm{P}$ is precipitation; AET is actual evapotranspiration; $\mathrm{Q}$ is runoff from the catchment;

$\mathrm{GW}_{\mathrm{R}}$ is groundwater recharge. 
The different water balance components have been computed using the following different techniques.

The mean annual rainfall was computed using arithmetical mean method. The areal pattern of the seasonality of rainfall in the study area was determined by analyzing mean monthly rainfall data for one station in the study area. To compare the monthly distribution of rainfall at this station, the method employed here was adapted from a study of precipitation data for the Awash River Basin (Daniel, 1974).This involved the calculation of "rainfall coefficient" for each month at the station, the coefficient being the ratio between the mean monthly rainfall and one-twelfth of the annual mean (the latter referred to as "rainfall module"). To distinguish between a "rainy" month and a "dry" month in the Awash Basin study, a month is designated "rainy" when the monthly rainfall coefficient reaches 0.6 (60\% of the rainfall module), and distinctly rainy when it exceeds 0.8. Extremely rainy months have a coefficient of more than 1 (that is, the rainfall exceeds the module value) (Daniel, 1974).

In this study, a month was designated "rainy" if the rainfall coefficient is 0.6 or over, as in the Awash Basin study. The term "small rains" is employed to refer to those months with a rainfall coefficient of 0.6 to 0.9 ; and the term "big rains" to those months where the coefficient is 1.0 and above. The "big" rainy months are further classified into three groups: those with "moderate concentration" of rainfall (coefficient of 1.0 to 1.9); those with "high concentration" of rainfall (coefficient of 2.0to 2.9); and those with "very high concentration" of rainfall (coefficient of 3.0 and above).

Potential evapotranspiration was calculated using Penman-Monteith and Thornthwaite methods so as to compare and contrast the result obtained. The potential evapotranspiration of the study area using Penman-Monteith method was determined by the CropWat for Windows computer program. The Thornthwaite method (Nata et al., 2010) uses air temperature as an index of the energy available for evapotranspiration, assuming that air temperature is correlated with the integrated effects of net radiation and other controls of evapotranspiration and the available energy is shared in fixed proportion between heating the atmosphere and evapotranspiration.

The Thornthwaite's empirical equation is:

$P E T=N_{m} 16\left[\frac{10 T_{n}}{J}\right]^{a}$ 
Where, PET $=$ Potential evapotranspiration $(\mathrm{mm} / \mathrm{month}) ; \mathrm{T}_{\mathrm{n}}=$ Mean monthly air temperature $\left({ }^{\circ} \mathrm{C}\right)$;

$\mathrm{n}=1,2,3$, .12 is the number of considered months;

$\mathrm{J}=$ Annual heat index and it is given by the equation;

$J=\sum_{n=1}^{12} j$.

$\mathrm{j}=$ Monthly heat index and it is expressed as:

$j=\left(\frac{T_{n}}{5}\right)^{1.514}$

$\mathrm{a}=0.49239+0.01792 \mathrm{~J}-0.0000771 \mathrm{~J}^{2}+0.000000675 \mathrm{~J}^{3}$.

$\mathrm{Nm}=$ Daylight correction factor for potential evapotranspiration (latitude dependent).

Actual evapotranspiration was computed using Thornthwaite soil-water balance model (Dunne and Leopold, 1978). The available water capacities for combinations of soil texture and vegetation were used for the determination of the available water capacity of root zone, which is suggested by Thornthwaite and Mather (1957). The total mean actual evapotranspiration that occurs in the catchment was determined by arithmetic mean of the annual actual evapotranspiration from each land use weighted by their area coverage.

$A E T_{T}=\sum \frac{A E T_{i} a_{i}}{A}$

Where, $\mathrm{AET}_{\mathrm{T}}$ is total actual evapotranspiration; $\mathrm{AET}_{\mathrm{i}}$ is mean annual actual evapotranspiration from each land use; $\mathrm{a}_{\mathrm{i}}$ is area of each land use; and $\mathrm{A}$ is total catchment area.

The volume of surface runoff that can be generated from the catchment was calculated using runoff coefficient method. According to Garg (1987), the runoff volume from the catchment can be computed by using the runoff coefficient method, which can be expressed by the following formula.

$\mathrm{Q}=\mathrm{C}^{*} \mathrm{P} * \mathrm{~A}$

Where, $\mathrm{Q}$ is runoff volume from the catchment $\left(\mathrm{m}^{3}\right)$; $\mathrm{P}$ is average precipitation $(\mathrm{m})$; $\mathrm{A}$ is catchment area $\left(\mathrm{m}^{2}\right)$; and, $\mathrm{C}$ is runoff coefficient.

The runoff coefficient $(\mathrm{C})$ in the runoff coefficient method was determined based on the land use, soil type (hydrological soil groups) and slope. The four hydrologic soil groups (HSGs) that are described by Suresh (2002) was used in the computation of runoff. 


\section{RESULTS AND DISCUSSION}

\subsection{Characterization of Physical Conservation Measures}

Different physical conservation measures were implemented with the aim to reduce slope length and to conserve surface runoff thereby increasing infiltration in the study area. Hillside terraces and stone check dams were constructed in the upper hillside of the catchment and deep trenches, series of ponds, SS dam, gabion check dam and percolation ponds were constructed in the foot of the slopes in order to capture the coming surface runoff. Physical conservation measures constructed in the foot of the hillside were characterized and the volumes of surface runoff that can be retained by these physical measures were computed using the measured dimensions of the structures (Table 1).

Table 1. Physical conservation measures and actual volume of surface runoff that can be contained by the structures (as it was measured in April 2012).

\begin{tabular}{|lllll|}
\hline No. & Type of physical SWC & Unit & $\begin{array}{l}\text { Volume } \\
\text { of work }\end{array}$ & $\begin{array}{l}\text { Volume of } \\
\text { runoff contained }\left(\boldsymbol{m}^{3}\right)\end{array}$ \\
\hline 1 & Deep Trench & No & 80 & 61,248 \\
\hline 2 & Series of ponds & No & 58 & $858,154.51$ \\
\hline 3 & SS dam & No & 37 & $5,407.51$ \\
\hline 4 & Gabion check dam & No & 15 & 275,694 \\
\hline 5 & Percolation ponds & No & 73 & 398,231 \\
\hline Total & & & & $1,598,735.02$ \\
\hline
\end{tabular}

Table 2. Suggested and calculated available water capacity of soil at the root zone.

\begin{tabular}{|llll|}
\hline Soil type & $\begin{array}{l}\text { Root } \\
\text { depth }(\boldsymbol{m})\end{array}$ & $\begin{array}{l}\text { Calculated } \text { AWC } \\
\text { at root depth }(\mathbf{m m} / \boldsymbol{m})\end{array}$ & $\begin{array}{l}\text { Suggested } \text { AWC } \\
\text { at root depth }(\mathbf{m m} / \boldsymbol{m})\end{array}$ \\
\hline Loamy sand & 1.85 & 247 & $250^{*}$ \\
\hline Sandy loam & 1.85 & 162 & $150^{*}$ \\
\hline Clay & 0.7 & 200.98 & $200^{*}$ \\
\hline Sand & 0.9 & 80 & $75^{*}$ \\
\hline Sandy loam & 0.9 & 155 & $150^{*}$ \\
\hline
\end{tabular}

* (Thornthwaite and Mather, 1957)

\subsection{Hydrology}

The hydrology of the catchment was examined based on land use, soil and climatic parameters such as rainfall, temperature, evapotranspiration and runoff. 


\subsubsection{Soil Water Holding Capacity}

The available water content of each soil layer in each pit and the total available water for the entire profile were computed using the Eq. 2, and the results are given in table 2.

The AWC estimated using the laboratory result was a little bit different from suggested available water content of the major soils of the study area.

\subsubsection{Rainfall}

\subsubsection{Mean Monthly Rainfall}

The mean monthly rainfall (Table 3, Fig 2) was averaged over eighteen years of record. Accordingly, the highest rainfall of the area is recorded in July and August, which accounts 73.2 $\%$ of the total mean annual rainfall of the study area whereas the minimum rainfall is recorded in December and January which accounts about $0.3 \%$ of the total mean annual rainfall of the study area. The study area receives mean annual rainfall of $565.8 \mathrm{~mm}$.

Table 3. Mean monthly rainfall (MMR) at Wukro station (mm).

\begin{tabular}{|llllllllllllll|}
\hline Months & Jan & Feb & Mar & Apr & May & Jun & Jul & Aug & Sep & Oct & Nov & Dec & Annual \\
\hline MMR & 0.52 & 2 & 17.5 & 30.09 & 24.59 & 43.04 & 203.66 & 210.55 & 24.61 & 5.31 & 2.85 & 1.09 & 565.81 \\
\hline
\end{tabular}

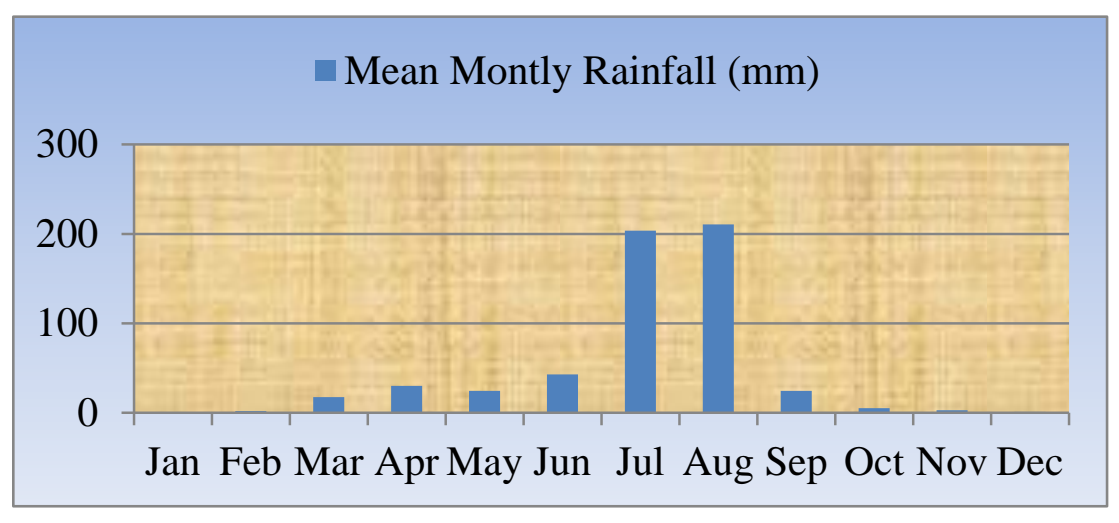

Figure 2. Mean monthly and annual rainfall values at Wukro station.

\subsubsection{Seasonality of Rainfall}

The catchment is characterized by two rainy seasons and three dry seasons during the year. The rainy seasons in total have four months which comprises of April, June, July and August whereas the dry season comprises of eight months (Table 4). 
The rains in April and June are small rains accounts $12.93 \%$ of the average annual rainfall of the catchment. Big rains with a very high concentration occur in July and August, and these accounts for $73.20 \%$ of the average annual rainfall of the watershed.

The first dry season starts in January and ends in March. The second dry season has only one month, May. The third one starts in September and ends in December. The amount of rainfall that occurs during the eight months of dry seasons in total accounts for $13.87 \%$ of the average annual rainfall of the catchment. The study area has not experienced high concentration of rainfall.

Table 4. Rainfall coefficient values and rainfall characteristics at Wukro station.

\begin{tabular}{|lllllllllllll|}
\hline Parameters & Jan & Feb & Mar & Apr & May & Jun & Jul & Aug & Sep & Oct & Nov & Dec \\
\hline RC & 0.01 & 0.04 & 0.37 & 0.64 & 0.52 & 0.91 & 4.32 & 4.47 & 0.52 & 0.11 & 0.06 & 0.02 \\
\hline Season & dry & dry & dry & rainy & dry & rainy & rainy & rainy & dry & dry & dry & dry \\
\hline Amount & - & - & - & SR & - & SR & BR & BR & - & - & - & - \\
\hline Concentration & - & - & - & - & - & - & VH & VH & - & - & - & - \\
\hline
\end{tabular}

Note: RC -Rainfall coefficient; SR- Small rain; BR -Big rain; VH -Very high concentration.

\subsubsection{Temperature}

The maximum and minimum temperature data of the study area was analyzed and the mean annual maximum and minimum temperature was found to be $27.9^{\circ} \mathrm{C}$ and $11^{\circ} \mathrm{C}$, respectively (Table 5). The mean annual air temperature of the study area is $18.7^{\circ} \mathrm{C}$. The mean monthly maximum and minimum air temperature were recorded in June and December having $21.32^{\circ} \mathrm{C}$ and $15.48^{\circ} \mathrm{C}$, respectively.

Table 5. Mean monthly temperatures at Wukro meteorological station $\left({ }^{\circ} \mathrm{C}\right)$.

\begin{tabular}{|lllllllllllll|}
\hline Parameters & Jan & Feb & Mar & Apr & May & Jun & Jul & Aug & Sep & Oct & Nov & Dec \\
\hline MMMT & 27.53 & 28.46 & 29.1 & 29.14 & 29.92 & 30.27 & 26.62 & 26.4 & 27.57 & 27.01 & 26.19 & 26.43 \\
\hline MMMiT & 8.32 & 9.3 & 11.61 & 13.45 & 13.4 & 12.55 & 12.36 & 13.04 & 10.98 & 10.19 & 9.13 & 7.93 \\
\hline MMAT & 17.68 & 18.63 & 20.05 & 20.99 & 20.39 & 21.32 & 18.77 & 18.31 & 19.15 & 17.87 & 15.83 & 15.48 \\
\hline
\end{tabular}

Note: MMMT -Mean monthly maximum temperature; MMMiT -Mean monthly minimum temperature; MMAT -Mean monthly air temperature. 


\subsubsection{Wind Speed, Solar Radiation and Relative Humidity}

The mean monthly wind speed values were computed and are given in the table 6. The maximum and minimum wind speed value is obtained in April $(2.55 \mathrm{~m} / \mathrm{s})$ and July $(1.29 \mathrm{~m} / \mathrm{s})$, respectively. In general the highest and lowest wind speed values are found both in the rainy months where rains occur in small and very high concentration, respectively. The mean monthly values were computed and are given in table 6. The maximum and minimum relative humidity value is found in August (77.13\%) and February (40.63\%) respectively. In general the highest humidity values are found in the rainy months whereas the lowest values are in dry months. The mean monthly sunshine hours of the area are given in table 6. The maximum sunshine hour is recorded in December (10.31 hours) whereas the minimum one is in July (4.64 hours). Generally, the maximum sunshine hours are found in dry months whereas the minimum are in very highly rainy months.

Table 6.Mean monthly wind speed, relative humidity and sunshine hours.

\begin{tabular}{|lllllllllllll|}
\hline Months & Jan & Feb & Mar & Apr & May & Jun & Jul & Aug & Sep & Oct & Nov & Dec \\
\hline WS(m/s) & 1.83 & 2.11 & 2.21 & 2.55 & 2.44 & 2.09 & 1.29 & 1.37 & 1.83 & 2.44 & 2.02 & 1.86 \\
\hline RH (\%) & 43.38 & 40.63 & 41.88 & 46.13 & 46.13 & 45.25 & 75.88 & 77.13 & 48.13 & 46.75 & 47.25 & 43.13 \\
\hline SH(hrs) & 10.04 & 10.13 & 9.39 & 9.41 & 9.23 & 7.38 & 4.64 & 5.64 & 7.93 & 9.13 & 9.76 & 10.31 \\
\hline
\end{tabular}

Note: WS is Wind speed; RH is Relative humidity; and, SH is Sunshine hours.

\subsubsection{Evapotranspiration}

\subsubsection{Potential Evapotranspiration}

The mean annual potential evapotranspiration value obtained by using Penman-Monteith and Thornthwaite method was $1787.39 \mathrm{~mm}$ and $832.67 \mathrm{~mm}$, respectively (Tables 7 \& 8). However, the value obtained by Penman-Monteith method seems exaggerated. Due to this reason, the potential evapotranspiration value obtained by Thornthwaite model is considered as a representative value for the studied area and considered further for the determination of actual evapotranspiration.

The mean monthly maximum value of potential evapotranspiration was obtained in June $(92.8 \mathrm{~mm})$ and the minimum value was obtained in December $(45.18 \mathrm{~mm})$. The maximum value

of monthly potential evapotranspiration occurs before the beginning of high rainy months in the 
rain season. In general, as we can see from table 8 the value of potential evapotranspiration fluctuates with corresponding mean monthly temperature.

Table 7. Potential Evapotranspiration calculated using Penman-Monteith method.

\begin{tabular}{|c|c|c|c|c|c|c|c|c|c|c|c|c|c|}
\hline $\begin{array}{l}\text { Para- } \\
\text { meters }\end{array}$ & Jan & Feb & Mar & Apr & May & Jun & Jul & Aug & Sep & Oct & Nov & Dec & Annual \\
\hline MMMT & 27.53 & 28.46 & 29.1 & 29.14 & 29.92 & 30.27 & 26.62 & 26.4 & 27.57 & 27.01 & 26.19 & 26.43 & \\
\hline MMMiT & 8.32 & 9.3 & 11.61 & 13.45 & 13.4 & 12.55 & 12.36 & 13.04 & 10.98 & 10.19 & 9.13 & 7.93 & \\
\hline $\mathrm{RH}(\%)$ & 43.38 & 40.63 & 41.88 & 46.13 & 46.13 & 45.25 & 75.88 & 77.13 & 48.13 & 46.75 & 47.25 & 43.13 & \\
\hline $\begin{array}{l}\text { WS } \\
(\mathrm{Km} / \mathrm{d})\end{array}$ & 158.1 & 182.3 & 190.9 & 220.3 & 210.8 & 180.6 & 111.5 & 118.4 & 158.1 & 210.8 & 174.5 & 160.7 & \\
\hline $\mathrm{SH}(\mathrm{hrs})$ & 10.04 & 10.13 & 9.39 & 9.41 & 9.23 & 7.38 & 4.64 & 5.64 & 7.93 & 9.13 & 9.76 & 10.31 & \\
\hline SR & 20.8 & 22.7 & 23.3 & 24.0 & 23.5 & 20.5 & 16.4 & 18.0 & 21.2 & 21.7 & 20.9 & 20.6 & \\
\hline $\begin{array}{l}\text { Eto } \\
(\mathrm{mm} / \mathrm{d})\end{array}$ & 4.44 & 5.20 & 5.61 & 5.98 & 6.09 & 5.43 & 3.59 & 3.79 & 4.88 & 5.13 & 4.45 & 4.24 & 1787.39 \\
\hline
\end{tabular}

Note: MMMT is Mean monthly maximum temperature $\left({ }^{\circ} \mathrm{C}\right)$; MMMiT is Mean monthly minimum temperature $\left({ }^{\circ} \mathrm{C}\right)$; RH is Relative humidity; WS is Wind speed; $\mathrm{SH}$ is Sunshine hours; $\mathrm{SR}$ is Solar radiation $\left(\mathrm{MJ} / \mathrm{m}^{2} / \mathrm{d}\right)$; and, ETo is Evapotranspiration $(\mathrm{mm} / \mathrm{d})$.

Table 8.Potential Evapotranspiration calculated using Thornthwaite formula.

\begin{tabular}{|llllllllllllll|}
\hline Month Jan & Feb & Mar & Apr & May & Jun & Jul & Aug & Sep & Oct & Nov & Dec Ann. \\
\hline T & 17.68 & 18.63 & 20.1 & 20.99 & 20.39 & 21.32 & 18.77 & 18.31 & 19.15 & 17.87 & 15.83 & 15.4 \\
& & & & & & & & & & & & 8 & \\
\hline J & 6.77 & 7.33 & 8.19 & 8.78 & 8.39 & 8.99 & 7.41 & 7.14 & 7.64 & 6.88 & 5.72 & 5.53 & 88.8 \\
\hline LCF at & 0.94 & 0.97 & 1 & 1.04 & 1.07 & 1.08 & 1.08 & 1.05 & 1.02 & 0.98 & 0.95 & 0.93 \\
$10^{\circ} \mathrm{N}$ & & & & & & & & & & & & & \\
\hline CPET & 59.07 & 64.71 & 77.7 & 87.50 & 84.32 & 92.82 & 71.81 & 67.78 & 72.53 & 61.55 & 47.67 & 45.2 & 832.7 \\
\hline
\end{tabular}

Note: $\mathrm{T}$-mean monthly air temperature $\left({ }^{\circ} \mathrm{C}\right) ; \mathrm{j}$ - monthly heat index; LCF- latitude correction factor at $10^{\circ} \mathrm{N}$; CPET -corrected or adjusted potential evapotranspiration (mm).

\subsubsection{Actual Evapotranspiration}

Actual evapotranspiration was estimated using Thornthwaite soil-water balance model. Accordingly, the mean annual actual evapotranspiration for the entire catchment was found to be $405.61 \mathrm{~mm}$. The computed values of actual evapotranspiration for different soil types of the catchment are given in the table 10-13. All these results are summarized and given in the table 9. 
Table 9. The summary of actual evapotranspiration of the catchment.

\begin{tabular}{|l|l|l|l|l|l|}
\hline No & Soil type & Area $\left(\boldsymbol{m}^{2}\right)$ & AET $(\boldsymbol{m})$ & ${\text { AET }\left(\boldsymbol{m}^{3}\right)}_{1}$ & $\begin{array}{c}\text { Mean Annual AET } \\
(\mathbf{m m})\end{array}$ \\
\hline 1 & Loamy sand & 1070815 & 0.5106 & 546758.139 & \\
\hline 2 & Sandy loam & 2999856 & 0.44747 & 1342345.564 & \\
\hline 3 & Sand & 5139183 & 0.37169 & 1910182.929 & \\
\hline 4 & clay & 850145.8 & 0.47858 & 406862.777 & \\
\hline 5 & Rock & 310000 & 0 & 0 & 405.61 \\
\hline
\end{tabular}

\subsubsection{Surface Runoff}

The volume of surface runoff generated within the catchment and escaping from the catchment has its own effect on water availability inside the catchment. The mean annual runoffs generated from the different land use of the catchment before and after intervention were computed and are discussed below.

\subsubsection{Surface Runoff before the Intervention}

The volume of surface runoff before the intervention was computed using the land use and runoff coefficient data before the intervention and the result is given in table 14 .

As it can be seen from table 14 the study area was highly characterized by intensive cultivation, bare land and grazing land. As the result of this situation, the runoff coefficient of the study area increases which intern resulted generation of huge amount surface runoff from constituting different landforms. Accordingly, the volume of surface runoff before the intervention was found to be $1,577,167 \mathrm{~m}^{3}$, which is $26.88 \%$ of the mean annual rainfall of the area.

Table 14.Surface runoff before the intervention (Source: BoARD, 1992).

\begin{tabular}{|lllllll|}
\hline Land use & Area $\left(\boldsymbol{m}^{2}\right)$ & HSGS & $\begin{array}{l}\text { Slope } \\
(\%)\end{array}$ & $\begin{array}{l}\text { Runoff } \\
\text { coefficient } \\
\left(\boldsymbol{C}_{\boldsymbol{i}}\right)\end{array}$ & $\begin{array}{l}\text { Average annual } \\
\text { rainfall }(\boldsymbol{P})(\boldsymbol{m})\end{array}$ & Runoff $Q\left(\boldsymbol{m}^{3}\right)$ \\
\hline Bush land & 1220000 & $\mathrm{~A}$ & $10-30$ & 0.13 & 0.5658 & 89735.88 \\
\hline Bare land & 2380000 & $\mathrm{D}$ & $10-30$ & 0.6 & 0.5658 & 807962.4 \\
\hline $\begin{array}{l}\text { Cultivated } \\
\text { land }\end{array}$ & 4570000 & $\mathrm{~A}$ & $0-6$ & 0.14 & 0.5658 & 361998.8 \\
\hline $\begin{array}{l}\text { Grazing } \\
\text { land }\end{array}$ & 2010000 & $\mathrm{C}$ & $0-6$ & 0.23 & 0.5658 & 261569.34 \\
\hline Home stead & 190000 & $\mathrm{~B}$ & $0-10$ & 0.52 & 0.5658 & 55901.04 \\
\hline Total & $10,370,000$ & & & & & $1,577,167$ \\
\hline
\end{tabular}


Table 10. Mean monthly water balance of the catchment for the soil with the available water capacity of $247 \mathrm{~mm}$. The soil is loamy sand with average root depth of $1.4 \mathrm{~m}$. All values in table are in millimeters.

\begin{tabular}{|l|l|l|l|l|l|l|l|l|l|l|l|l|l|}
\hline Months & Jan & Feb & Mar & Apr & May & Jun & Jul & Aug & Sep & Oct & Nov & Dec & Annual \\
\hline P & 0.52 & 2 & 17.5 & 30.09 & 24.59 & 43.04 & 203.66 & 210.55 & 24.61 & 5.31 & 2.85 & 1.09 & \\
\hline CPET & 59.09 & 64.71 & 77.73 & 87.5 & 84.32 & 92.82 & 71.81 & 67.78 & 72.53 & 61.55 & 47.67 & 45.18 & \\
\hline P- CPET & -58.57 & -62.71 & -60.23 & -57.41 & -59.73 & -49.78 & 131.85 & 142.77 & -47.92 & -56.24 & -44.82 & -44.09 & \\
\hline Acc. Pot. WL & -251.64 & -314.35 & -374.58 & -431.99 & -491.72 & -541.50 & & & -47.92 & -104.16 & -148.98 & -193.07 & \\
\hline SM & 89.16 & 69.16 & 5418 & 42.97 & 33.73 & 27.59 & 247 & 247 & 203.44 & 161.97 & 135.15 & 113.00 & \\
\hline$\Delta$ SM & -23.84 & -20.00 & -14.98 & -11.21 & -9.24 & -6.14 & 219.41 & 0 & -43.56 & -41.47 & -26.82 & -22.15 & \\
\hline ETactual & 24.36 & 22.00 & 32.48 & 41.30 & 33.83 & 49.18 & 71.81 & 67.78 & 68.17 & 46.78 & 29.67 & 23.24 & 510.6 \\
\hline
\end{tabular}

Table 11. Mean monthly water balance of the catchment for the soil with an available water capacity of $162 \mathrm{~mm}$. The soil is sandy loam with an average root depth of $1.85 \mathrm{~m}$. All values in table are in millimeters

\begin{tabular}{|c|c|c|c|c|c|c|c|c|c|c|c|c|c|}
\hline Months & Jan & Feb & Mar & Apr & May & Jun & Jul & Aug & Sep & Oct & Nov & Dec & Annual \\
\hline $\mathrm{P}$ & 0.52 & 2 & 17.5 & 30.09 & 24.59 & 43.04 & 203.66 & 210.55 & 24.61 & 5.31 & 2.85 & 1.09 & \\
\hline CPET & 59.09 & 64.71 & 77.73 & 87.5 & 84.32 & 92.82 & 71.81 & 67.78 & 72.53 & 61.55 & 47.67 & 45.18 & \\
\hline P- CPET & -58.57 & -62.71 & -60.23 & -57.41 & -59.73 & -49.78 & 131.85 & 142.77 & -47.92 & -56.24 & -44.82 & -44.09 & \\
\hline $\begin{array}{l}\text { Acc. Pot. } \\
\text { WL }\end{array}$ & -251.64 & -314.35 & -374.58 & -431.99 & -491.72 & -541.50 & & & -47.92 & -104.16 & -148.98 & -193.07 & \\
\hline SM & 34.28 & 23.28 & 16.05 & 11.25 & 7.79 & 5.72 & 162 & 162 & 120.49 & 85.17 & 64.56 & 49.19 & \\
\hline$\Delta \mathrm{SM}$ & -14.91 & -11 & -7.23 & 4.80 & -3.46 & -2.07 & 156.28 & 0 & -41.51 & -35.32 & -20.61 & -15.37 & \\
\hline ETactual & 15.43 & 13 & 24.73 & 34.89 & 28.05 & 45.11 & 71.81 & 67.78 & 66.12 & 40.63 & 23.46 & 16.46 & 447.47 \\
\hline
\end{tabular}


Table 12. Mean monthly water balance of the catchment for the soil with an available water capacity of $80.6 \mathrm{~mm}$. The soil is sand soil with an average root depth of $0.85 \mathrm{~m}$. All values in table are in millimeters.

\begin{tabular}{|c|c|c|c|c|c|c|c|c|c|c|c|c|c|}
\hline Months & Jan & Feb & Mar & Apr & May & Jun & Jul & Aug & Sep & Oct & Nov & Dec & Annual \\
\hline $\mathrm{P}$ & 0.52 & 2 & 17.5 & 30.09 & 24.59 & 43.04 & 203.66 & 210.55 & 24.61 & 5.31 & 2.85 & 1.09 & \\
\hline CPET & 59.09 & 64.71 & 77.73 & 87.5 & 84.32 & 92.82 & 71.81 & 67.78 & 72.53 & 61.55 & 47.67 & 45.18 & \\
\hline P- CPET & -58.57 & -62.71 & -60.23 & -57.41 & -59.73 & -49.78 & 131.85 & 142.77 & -47.92 & -56.24 & -44.82 & -44.09 & \\
\hline Acc. Pot. WL & -251.64 & -314.35 & -374.58 & -431.99 & -491.72 & -541.50 & & & -47.92 & -104.16 & -148.98 & -193.07 & \\
\hline SM & 3.55 & 1.63 & 0.77 & 0.38 & 0.18 & 0.10 & 80.6 & 80.6 & 44.46 & 22.14 & 12.70 & 7.35 & \\
\hline$\Delta \mathrm{SM}$ & -3.80 & -1.92 & -0.86 & -0.39 & -0.20 & -0.08 & 80.5 & 0 & -36.14 & -22.32 & -9.44 & -5.35 & \\
\hline ETactual & 4.32 & 3.92 & 18.36 & 30.48 & 24.79 & 43.12 & 71.81 & 67.78 & 60.75 & 27.63 & 12.29 & 6.44 & \begin{tabular}{|l|}
371.69 \\
\end{tabular} \\
\hline
\end{tabular}

Table 13. Mean monthly water balance of the catchment for the soil with an available water capacity of $200.98 \mathrm{~mm}$. The soil is clay soil with an average root depth of $0.7 \mathrm{~m}$. All values in table are in millimeters.

\begin{tabular}{|c|c|c|c|c|c|c|c|c|c|c|c|c|c|}
\hline Months & Jan & Feb & Mar & Apr & May & Jun & Jul & Aug & Sep & Oct & Nov & Dec & Annual \\
\hline $\mathrm{P}$ & 0.52 & 2 & 17.5 & 30.09 & 24.59 & 43.04 & 203.66 & 210.55 & 24.61 & 5.31 & 2.85 & 1.09 & \\
\hline CPET & 59.09 & 64.71 & 77.73 & 87.5 & 84.32 & 92.82 & 71.81 & 67.78 & 72.53 & 61.55 & 47.67 & 45.18 & \\
\hline P- CPET & -58.57 & -62.71 & -60.23 & -57.41 & -59.73 & -49.78 & 131.85 & 142.77 & -47.92 & -56.24 & -44.82 & -44.09 & \\
\hline Acc. Pot. WL & -251.64 & -314.35 & -374.58 & -431.99 & -491.72 & -541.50 & & & -47.92 & -104.16 & -148.98 & -193.07 & \\
\hline SM & 57.47 & 42.06 & 31.16 & 23.43 & 17.40 & 13.59 & 200.98 & 200.98 & 158.41 & 119.73 & 95.79 & 76.88 & \\
\hline$\Delta \mathrm{SM}$ & -19.41 & -15.41 & -10.90 & -7.73 & -6.03 & -3.81 & 187.39 & 0 & -42.57 & -38.68 & -23.94 & -18.91 & \\
\hline ETactual & 19.93 & 17.41 & 28.40 & 37.82 & 30.62 & 46.85 & 71.81 & 67.78 & 67.18 & 43.99 & 26.79 & 20.00 & 478.58 \\
\hline
\end{tabular}

Note: $\mathrm{P}$ is mean monthly precipitation; CPET is corrected potential evapotranspiration; P - CPET is difference by subtraction; Acc. Pot. WL is accumulated potential water loss; $\mathrm{SM}$ is soil moisture; $\triangle \mathrm{SM}$ is change in soil moisture during the month; and ETactual is actual evapotranspiration. 


\subsubsection{Surface Runoff after the Intervention}

The computation of runoff was done by classifying the catchment into different land use, slope class and the hydrologic soil groups, and the result is summarized and given in the table below.

Table 15. Surface runoff after the intervention.

\begin{tabular}{|c|c|c|c|c|c|c|}
\hline Land use & $\operatorname{Area}\left(m^{2}\right)$ & HSGS & $\begin{array}{l}\text { Slope } \\
(\%)\end{array}$ & $\begin{array}{l}\text { Runoff } \\
\text { coefficient }\left(C_{i}\right)\end{array}$ & $\begin{array}{l}\text { Mean annual } \\
\text { rainfall } P(m)\end{array}$ & $\begin{array}{l}\text { Runoff } \\
Q\left(m^{3}\right)\end{array}$ \\
\hline \multirow[t]{2}{*}{ Bush land } & 3690000 & $\mathrm{~B}$ & $10-30$ & 0.16 & 0.5658 & 334048.32 \\
\hline & 350,000 & $\mathrm{~A}$ & $10-30$ & 0.13 & 0.5658 & 25743.9 \\
\hline \multirow{3}{*}{$\begin{array}{l}\text { Cultivated } \\
\text { land }\end{array}$} & $4,300,000$ & $\mathrm{~A}$ & $0-6$ & 0.14 & 0.5658 & 340611.6 \\
\hline & 570,000 & $\mathrm{~B}$ & $0-6$ & 0.18 & 0.5658 & 58051.08 \\
\hline & 50,000 & $\mathrm{C}$ & $0-6$ & 0.19 & 0.5658 & 5375.1 \\
\hline $\begin{array}{l}\text { Grazing } \\
\text { land }\end{array}$ & 800,000 & $\mathrm{C}$ & $0-6$ & 0.23 & 0.5658 & 104107.2 \\
\hline Bare land & 310,000 & $\mathrm{D}$ & $10-30$ & 0.6 & 0.5658 & 105238.8 \\
\hline $\begin{array}{l}\text { Home } \\
\text { stead }\end{array}$ & 300,000 & $\mathrm{~B}$ & $0-6$ & 0.21 & 0.5658 & 35645.4 \\
\hline Total & 10370000 & & & & & $1,008,821$ \\
\hline
\end{tabular}

Note: HSGS is hydrologic soil groups; * Source: Co-SAERT (2000).

The surface runoff after the intervention was found to be $1,008,821.4 \mathrm{~m}^{3}$, which is $17.19 \%$ of total rainfall. There is $9.69 \%$ decrease in surface runoff after the intervention. This decrease in the runoff is mainly due to the intervention of integrated soil and water conservation measures that create an opportunity for the water that was used to left the area as a surface runoff to percolate and recharge the groundwater.

\subsubsection{Water Balance}

\subsubsection{Water Balance before the Intervention}

The input component of the catchment is precipitation and the output components are actual evapotranspiration and runoff. Using the water balance equation the amount of water that infiltrated into the ground was calculated.

$\mathrm{P}-\mathrm{AET}-\mathrm{Q}_{\mathrm{B}}-\mathrm{GW}_{\mathrm{RB}}=0$

Where, $\mathrm{P}$ is precipitation $\left(5,867,346 \mathrm{~m}^{3}\right) ; \mathrm{Q}_{\mathrm{B}}$ is surface runoff before the intervention $\left(1,577,167 \mathrm{~m}^{3}\right)$; AET is actual evapotranspiration $\left(4,206,149.41 \mathrm{~m}^{3}\right)$; and $\mathrm{GWR}_{\mathrm{B}}$ is groundwater recharge before the intervention. 
Therefore;

$\mathrm{GW}_{\mathrm{RB}}=5,867,346-(4,206,149.41+1,577,167) \mathrm{m}^{3}$

$\mathrm{GW}_{\mathrm{RB}}=84,029.59 \mathrm{~m}^{3}$

The volume of water that percolate down and join the groundwater before the intervention was found to be $84,029.59 \mathrm{~m}^{3}$ which is $1.43 \%$ of the mean annual rainfall of the catchment.

\subsubsection{Water balance after the Intervention}

The input and output component of water balance includes precipitation, actual evapotranspiration and runoff after the intervention.

P-AET- $\mathrm{Q}_{\mathrm{A}}-\mathrm{GW}_{\mathrm{RA}}=0$.

Where, $\mathrm{P}$ is precipitation $\left(5,867,346 \mathrm{~m}^{3}\right) ; \mathrm{Q}_{\mathrm{A}}$ is surface runoff after the intervention $\left(1,008,821.4 \mathrm{~m}^{3}\right)$; AET is actual evapotranspiration $\left(4,206,149.41 \mathrm{~m}^{3}\right)$; and, $\mathrm{GW}_{\mathrm{RA}}$ is groundwater recharge after the intervention.

Therefore;

$\mathrm{GW}_{\mathrm{RA}}=5,867,346-\left(4,206,149.41+1,008,821.4 \mathrm{~m}^{3}\right) \mathrm{m}^{3}$

$\mathrm{GW}_{\mathrm{RA}}=652,375.19 \mathrm{~m}^{3}$

The volume of water that percolate down and join the groundwater after the intervention was found to be $652,375.19 \mathrm{~m}^{3}$ which is $11.12 \%$ of the mean annual rainfall of the catchment.

Surface runoff that are generated from the upper bush land and bare land that has a total amount of $465,031.02 \mathrm{~m}^{3}$ is captured by the various physical conservation structures which are constructed at the foot hillsides the catchment. This amount is an additional amount that percolates deep into the ground. As a result, the actual groundwater recharge after the intervention was found to be $1,117,406.21 \mathrm{~m}^{3}(19.04 \%$ of the mean annual rainfall of the catchment).

\section{CONCLUSION}

After the implementation of ISWC in the catchment, the volume of runoff that is generated from the different land use of the catchment is reduced by the amount of $568,345.6 \mathrm{~m}^{3}$ and the groundwater recharge is increased by $1,033,376.62 \mathrm{~m}^{3}$. The availability of the water in the catchment is increased by 17.61 per cent of the mean annual rainfall of the catchment. This result is supported by the availability of groundwater in the down stream of the catchment. The hand dug wells that are found drilled in the down stream side of the catchment are rich in groundwater 
and farmers currently are utilizing this water for complimentary irrigation during dry season and supplementary irrigation in the rainy season where the rain get scarcity.

Since the study area is characterized by high intensity of rainfall during two months and which can produce high surface runoff, and additional physical conservation structures are suggested to be constructed to capture $100 \%$ of produced runoff.

For better results and production land suitability evaluation should be carried out before the implementation of different management intervention.

In order to maintain the continuity of proper land management, all stake holders should give due attention and provide the required support.

\section{ACKNOWLEDGEMENTS}

This paper forms part of the M.Sc thesis submitted to the Department of Land Resources Management and Environmental Protection, College of Dry Land Agriculture and Natural Resources Management, Mekelle University. The author, Tireza N duly acknowledges The Tigray Bureau of Agriculture and Rural Development office for funding this research project. Thanks are due to Prof. Dharmapuram Reddy, Dr. Solomon and Dr. K. Bheemalingeswara for their comments and suggestions which have improved the quality of the paper considerably.

\section{REFERENCE}

Badege Bishaw. 2001. Deforestation and land degradation in Ethiopian high lands: a strategy for physical recovery. Oregon state university, Corvallis North East African studies (ISSN 0740-9133) 8(1)1(New Series):7-26.

Bureau of Agriculture and Rural Development (BoARD). 1992. Natural Resource Report. Aberha Atsebha Woreda, Tigray, Ethiopia.

CO-SAERT. 2000. Design and Construction of Physical Soil and Water ConservationStructures. Daniel Dannano-concert engineering and consulting enterprise P.L.C (CECE).

Daniel Gemechu. 1974. Aspects of climate and water budget in Ethiopia.Addis Ababa University Press, Addis Ababa.

Dunne, T \& Leopold, L. B. 1978. Water in environmental planning. W. H. Freeman, ISBN-10: 0716700794, ISBN-13: 978-0716700791, xxvii, 818p. 
Fitsum Hagos, John Pender \& Nega Gebreselassie. 1999. Land degradation in the highlands of Tigray and strategies for sustainable land management. Socioeconomic and Policy Research Working Paper No. 25 Addis Ababa, Ethiopia.

Garg, K. 1987. Irrigation engineering and hydraulic structures, India: Khanna Publishers, pp. 197-353.

Nata Tadesse, Shishay Tadios \& Mekdes Tesfay. 2010. The Water balance of May Nugus Catchment, Tigray, Northern Ethiopia. International Journal of Earth Sciences and Engineering, 3(5): 609-625.

Radwan, G. A. 2009. Using hydrological and meteorological data for computing the water budget in Lake Qarun, Egypt. National Institute of Oceanography and Fisheries, Egypt.

Stephen A. Thompson. 1999. Hydrology for Water Management, A. A. Balkema, Rotterdam, $450 \mathrm{p}$.

Suresh, R. 2002. Soil and Water Conservation Engineering, Standard Publishers Distributors, $4^{\text {th }}$ Edition, ISBN: 9788180140006, New Delhi, 951p.

Thornthwaite, C.W., Mather, J.R \& Carter, D.B. 1957. Instructions and tables for computing potential evapotranspiration and the water balance. Publication Series in Climatology, Drexel Institute of Technology, Laboratory of Climatology, Centerton, N.J. Volume 10, No.3, $127 \mathrm{p}$. 